\title{
PENGARUH KOMUNIKASI TERAPEUTIK PERAWAT TERHADAP TINGKAT KECEMASAN PADA PASIEN PRA OPERASI
}

\section{The Influence of Nurse Therapeutic Communication Towards Anxiety Level on Preoperative Patients}

\author{
Farida Febriyanti ${ }^{1}$, I Nyoman Sutresna ${ }^{2}$, Claudia Wuri Prihandini ${ }^{3}$ \\ ${ }^{I}$ Mahasiswa Program Studi S1 Keperawatan, STIKES Bina Usada Bali, Badung, Bali, Indonesia \\ ${ }^{2}$ Departemen Keperawatan Dasar, STIKES Bina Usada Bali, Badung, Bali, Indonesia \\ ${ }^{2}$ Departemen Keperawatan Jiwa, STIKES Bina Usada Bali, Badung, Bali, Indonesia \\ Korespondensi : faridafebriyanti96@gmail.com
}

\begin{abstract}
ABSTRAK
Kecemasan merupakan perasaan yang tidak menyenangkan yang dapat mempengaruhi respon fisiologis dan psikologis. Tujuan penelitian ini untuk mengetahui pengaruh komunikasi terapeutik perawat terhadap tingkat kecemasan pada pasien pra operasi. Rancangan penelitian ini adalah pre experimental design, mengunakan two grup pretest-postest, dengan jumlah sampel sebanyak 15 orang untuk tiap kelompok. Teknik sampling yang digunakan adalah nonprobability sampling, yaitu quota sampling dan menggunakan uji wilcoxon. Dari hasil uji Wilcoxon pada kelompok perlakuan diperoleh nilai $\mathrm{p}=0,005$ maka dapat disimpulkan bahwa pemberian komunikasi terapeutik efektif menurunkan tingkat kecemasan pada pasien pra operasi. Pada kelompok kontrol, hasil uji wilcoxon diperoleh nilai $\mathrm{p}=1,000$ maka dapat disimpulkan bahwa tidak ada perubahan tingkat kecemasan pada pasien yang tidak dilakukan komunikasi terapeutik. Hasil penelitian ini dapat digunakan, agar perawat tetap memperhatikan kecemasan pada pasien pra operasi dan melakukan pendekatan dengan tehnik komunikasi terapeutik.
\end{abstract}

Kata Kunci: komunikasi terapeutik, kecemasan, pra operasi

\begin{abstract}
Anxiety is an unpleasant feeling that can affect physiological and psychological responses. The purpose of this study was to determine the effect of nurse therapeutic communication on anxiety levels in preoperative patients. The design of this study was pre-experimental design, using two groups of pretest-posttest, with a total sample of 15 people for each group. The sampling technique used was nonprobability sampling, namely quota sampling and using the Wilcoxon test. From the results of the wilcoxon test in the treatment group obtained a value of $p=0.005$, it can be concluded that the provision of therapeutic communication is effective in reducing the level of anxiety in preoperative patients. In the control group, the results of the wilcoxon test obtained a value of $p=1,000$ so it can be concluded that there was no change in the level of anxiety in patients who did not have therapeutic communication. The results of this study can be used, so that nurses continue to pay attention to anxiety in preoperative patients and approach therapeutic communication techniques.
\end{abstract}

Keywords: therapeutic communication, anxiety, preoperative 
Farida Febriyanti, dkk: Pengaruh Komunikasi Terapeutik Perawat Terhadap Tingkat Kecemasan Pada Pasien Pra Operasi

\section{PENDAHULUAN}

Tindakan operasi merupakan pengalaman yang biasa menimbulkan kecemasan.Kecemasan terjadi karena berhubungan dengan segala macam prosedur asing yang dijalani pasien dan juga ancaman terhadap keselamatan jiwa akibat prosedur pembedahan.Kecemasan pada pasien pra operasi, ditandai dengan perasaan ketakutan dan gelisah serta menggambarkan perasaan keragu-raguan, keadaan tidak berdaya, tegang, gelisah dan khawatir terhadap sesuatu yang mengancam (Ismiyatun, 2017). Kecemasan pada pasien pra operasi berdampak pada jalannya operasi apalagi pada pasien dengan riwayat hipertensi jika mengalami kecemasan akan berdampak pada sistem kardiovaskuler dengan peningkatan tekanan darah sehingga operasi dapat dibatalkan.

Prevalensi secara umum gangguan kecemasan pra operasi adalah sebanyak $90 \%$ (Carpenito, 2013). Prevalensi gangguan kecemasan pra operasi di Amerika Serikat lebih dari 23 juta penduduk dan kurang dari $25 \%$ mengalami gangguan panik, sedangkan di Indonesia berkisar antara 6-7\% dari populasi umum (Ismiyatun, 2017). Warsini, Irwanti, \& Siswanto (2016) menemukan, tingkat kecemasan pasien pra operasi yaitu sebesar 44,4\% mengalami kecemasan sedang. Demikian pula hasil penelitian Mulyani, Paramastri, \& Priyanto (2008), di Rumah Sakit Elizabeth Situbondo, mendapatkan kecemasan pada pasien pra operasi, yaitu sebesar $52,5 \%$ cemas ringan dan $47,5 \%$ cemas sedang. Artini, Praptil, \& Putu (2017), mengungkapkan temuan tingkat kecemasan pasien pra operasi sebesar $3,4 \%$ cemas berat, $70,5 \%$ cemas sedang, dan $15,3 \%$ cemas ringan.

Kecemasan dapat dikurangi dengan tindakan keperawatan fokus pada komunikasi terapeutik dan pendidikan kesehatan bagi pasien dan keluarganya. Komunikasi terapeutik merupakan hubungan interpersonal antara perawat dan klien. Perawat dan klien memperoleh pengalaman belajar bersama dalam rangka memperbaiki pengalaman emosional klien. Komunikasi terapeutik merupakan komunikasi profesional antara perawat dan pasiennya, sehingga akan terjalin hubungan saling percaya antara perawat dengan pasiennya (Purwaningsih \& Karlina, 2012).

Pemberian komunikasi terapuetik melalui penjelasan persiapan sebelum dilakukan tindakan operasi, diharapkan mampu menurunkan tingkat kecemasan pasien pra operasi. Pemberian komunikasi terapeutik yang diberikan perawat terhadap pasien berisi tentang diagnosa penyakit, manfaat, urgensinya tindakan medis, resiko, komplikasi yang mungkin terjadi, alternatif prosedur lain yang dapat dilakukan, konsekuensi apabila tidak dilakukan tindakan medis, prognosis penyakit, dampak yang ditimbulkan dari tindakan medis serta keberhasilan/ketidakberhasilan dari tindakan medis. Pasien nantinya diharapkan akan mengetahui informasi tindakan yang akan dilakukan dokter ketika pasien dalam posisi tidak sadar dan akan merasa lebih tenang dalam menjalani tindakan invasif bedah, sehingga dapat menurunkan tingkat stres yang dialaminya (Asmadi, 2008).

Berdasarkan hasil studi pendahuluan yang dilakukan pada tanggal 15 Mei 2018 dengan 10 orang pasien pra operasi, didapatkan data bahwa 8 orang pasien mengatakan merasa cemas. Keluhan yang dirasakan secara subyektif yaitu pasien mengatakan merasa cemas, jantung berdebar-debar dan tidak bisa tenang. Data obyektif yang didapatkan pasien terlihat gelisah dan ekstremitas teraba dingin. Kecemasan yang dirasakan umumnya berkaitan dengan prosedur operasi yang akan dijalani serta akibat yang ditimbulkan setelah menjalani operasi.

\section{TUJUAN PENELITIAN}

Tujuan penelitian ini adalah untuk mengetahui pengaruh komunikasi terapeutik perawat terhadap tingkat kecemasan pasien pra operasi di Ruang Rawat Inap Rumah Sakit Tingkat II Udayana.

\section{METODE PENELITIAN}

Desain

Penelitian ini adalah penelitian quasi experiment dengan pendekatan nonequivalent with control group. 
Farida Febriyanti, dkk: Pengaruh Komunikasi Terapeutik Perawat Terhadap Tingkat Kecemasan Pada Pasien Pra Operasi

\section{Populasi dan Sampel}

Populasi dalam penelitian ini adalah seluruh pasien yang akan melakukan operasi di Rumah Sakit Tingkat II Udayana. Jumlah sampel sebanyak 15 orang pada masingmasing kelompok dengan teknik pengambilan sampel menggunakan quota sampling.

\section{Tempat dan Waktu Penelitian}

Penelitian ini bertempat di Ruang Rawat Inap Rumah Sakit Tingkat II Udayana. Penelitian dilaksanakan selama 6 minggu.

\section{Instrumen dan Prosedur Pengukuran}

Penelitian ini menggunakan Hamilton Rating Scale for Anxiety (HARS) sebagai alat ukur variabel kecemasan. Pengukuran kecemasan dilakukan sebelum diberikan intervensi dan setelah diberikan intervensi pada kelompok perlakuan.

\section{Analisa Data}

Analisa data yang digunakan dalam penelitian ini adalah wilcoxon sign rank test.

\section{Intervensi}

Intervensi yang diberikan kepada kelompok perlakuan adalah komunikasi terapeutik berupa tindakan penyuluhan kesehatan.

\section{HASIL PENELITIAN}

Hasil penelitian sebagai berikut:

\section{Tabel 1}

Karakteristik Responden Pra-Operasi di di Rumah Sakit Tingkat II Udayana $(\mathrm{n}=30)$

\begin{tabular}{lcc}
\hline Karakteristik Responden & f & $\mathbf{\%}$ \\
\hline Umur & & \\
20-25 tahun & 1 & 3,3 \\
26-35 tahun & 15 & 50 \\
36-45 thun & 14 & 46,7 \\
Jenis Kelamin & & \\
Laki-Laki & 12 & 40 \\
Perempuan & 18 & 60 \\
Pendidikan & & \\
SMP & 2 & 6,7 \\
SMA & 19 & 63,3 \\
PT & 9 & 30 \\
Pekerjaan & & \\
PNS & 4 & 13,3 \\
SWASTA & 13 & 43,3 \\
IRT & 10 & 33,4 \\
TNI & 3 & 10 \\
\hline
\end{tabular}

Pada tabel 1 diketahui usia responden didominasi 26-35 tahun (50\%). Jenis kelamin responden sebagian besar adalah perempuan $(60 \%)$. Tingkat pendidikan terlihat bahwa responden berpendidikan SMA (63,3\%). Jika dilihat dari karakteristik pekerjaan, responden didominasi oleh pekerja swasta $(43,3 \%)$.

Tabel 2

Pengaruh Komunikasi Terapeutik Terhadap Tingkat Kecemasan Pada Pasien PraOperasi $(n=30)$

\begin{tabular}{|c|c|c|c|c|c|}
\hline \multirow[b]{2}{*}{ Variabel } & \multicolumn{3}{|c|}{ Tingkat Kecemasasn } & \multirow[b]{2}{*}{$\mathrm{P}$} & \multirow[b]{2}{*}{ Z } \\
\hline & $\begin{array}{l}\text { Tidak } \\
\text { Cemas }\end{array}$ & $\begin{array}{l}\text { Cemas } \\
\text { Ringan }\end{array}$ & $\begin{array}{l}\text { Cemas } \\
\text { Sedang }\end{array}$ & & \\
\hline pre-test Klp. & 0 & 10 & 5 & & \\
\hline $\begin{array}{l}\text { Perlakuan } \\
\text { post-test Klp. } \\
\text { Perlakuan }\end{array}$ & 3 & 12 & 0 & 0.005 & -2.828 \\
\hline pre-test Klp. & 0 & 11 & 4 & & \\
\hline $\begin{array}{l}\text { Kontrol } \\
\text { post-test Klp. } \\
\text { Kontrol }\end{array}$ & 0 & 11 & 4 & 1.000 & 0.000 \\
\hline
\end{tabular}

Tabel 2 menunjukkan bahwa pada kelompok perlakuan, yang mengalami cemas ringan sebanyak 10 orang dan cemas sedang sebanyak 15 orang.Pada kelompok kontrol, yang mengalami cemas ringan sebanyak 11 orang dan cemas sedang sebanyak 4 orang. Pada kelompok perlakuan, yang tidak mengalami kecemasan sebanyak 3 orang dan cemas ringan sebanyak 12 orang.Pada kelompok kontrol, yang mengalami cemas ringan sebanyak 11 orang dan cemas sedang sebanyak 4 orang. Hasil uji wilcoxon pada kelompok perlakuan diperoleh nilai $\mathrm{p}=0,005$ maka dapat disimpulkan bahwa pemberian komunikasi terapeutik efektif menurunkan tingkat kecemasan pada pasien pra operasi. Pada kelompok kontrol, hasil uji Wilcoxon diperoleh nilai $\mathrm{p}=1,000$ maka dapat disimpulkan bahwa tidak ada perubahan tingkat kecemasan pada pasien yang tidak dilakukan komunikasi terapeutik.

\section{PEMBAHASAN}

Komunikasi terapeutik merupakan metode pemberian penyuluhan. Penyuluhan menggunakan komunikasi terapeutik dilakukan sesuai dengan permasalahan yang muncul. Hasil penelitian menunjukkan 
Farida Febriyanti, dkk: Pengaruh Komunikasi Terapeutik Perawat Terhadap Tingkat Kecemasan Pada Pasien Pra Operasi

bahwa sebelum diberikan komunikasi terapeutik, pada kelompok perlakuan, yang mengalami cemas ringan sebanyak 10 orang dan cemas sedang sebanyak 5 orang. Pada kelompok kontrol, yang mengalami cemas ringan sebanyak 11 orang dan cemas sedang sebanyak 4 orang. Hal ini menunjukkan bahwa seluruh pasien pada penelitian ini, mengalami kecemasan baik dalam tingkatan ringan maupun sedang. Hal ini sesuai dengan pendapat Carpenito (2013), bahwa kecemasan pada pasien, berkaitan dengan menghadapi lingkungan yang baru dan menjalani prosedur tindakan medis tertentu seperti operasi. Demikian pula penelitian yang dilakukan Mulyani et al. (2008), menemukan bahwa pada pasien pra operasi sectio sesarea, sebanyak $52,5 \%$ pasien mengalami tingkat kecemasan ringan dan 47,5\% kecemasan sedang.

Kecemasan pada pasien pra-operasi merupakan hal yang normal. Pasien pembedahan elektif akan merasa cemas dengan prosedur pembiusan dan prosedur tindakan operasi. Perawat harus dapat membantu mengatasi masalah kecemasan pasien sebelum operasi (Mirantia, Harmilah, \& Surantana, 2017). Interaksi antara perawat dan pasien secara terapeutik akan menghasilkan informasi tentang keadaan pasien serta bagaimana menyelesaikan masalah kecemasannya, serta kehadiran perawat dapat membantu mengurangi kecemasan terkait operasi (Stuart, 2007).

Stuart (2007), menjelaskan terdapat banyak faktor yang mempengaruhi efektivitas dari komunikasi efektif terhadap tingkat kecemasan seperti pendidikan, status ekonomi/pekerjaan, umur dan jenis kelamin. Hal ini 50 sesuai dengan data demografi dari responden dimana didominasi dengan pasien berjenis kelamin perempuan sebanyak 18 orang $(60 \%)$, berpendidikan SMA yaitu sebanyak 19 orang $(63,3 \%)$ dan pekerja swasta sebanyak 13 orang (43,3\%). Asmadi (2008), menyebutkan bahwa dengan pemberian komunikasi terapeutik mengenai prosedur pelaksanaan operasi merupakan stimulus tersendiri bagi individu sehingga individu akan memberikan respon baik yang adaptif sehingga setelah dilakukan pemberian komunikasi terapeutik tingkat kecemasan pasien pra-operasi akan mengalami penurunan.

\section{KESIMPULAN}

Implikasi

Hasil penelitian menunjukkan bahwa secara statistik dapat dibuktikan terdapat pengaruh pemberian komunikasi terapeutik menurunkan tingkat kecemasan pada pasien pra operasi di Ruang Rawat inap Rumah Sakit Tingkat II Udayana pada kelompok perlakuan. Komunikasi terapeutik dapat dilakukan melalui komunikasi verbal maupun non-verbal. Tindakan ini dapat membantu terbentuknya suasana yang terpeutik sehingga meningkatkan rasa nyaman pada pasien serta menurunkan kecemasan.

\section{Keterbatasan}

Pada pelaksanaan penelitian terdapat beberapa keterbatasan seperti waktu yang dibutuhkan dalam pengumpulan data lebih lama dari waktu yang telah ditentukan.

\section{DAFTAR PUSTAKA}

Artini, N. M., Prapti, N. K. G., \& Putu, I. G. N. (2017). Hubungan Terapeutik Perawat-Pasien Terhadap Tingkat Kecemasan Pasien Pre Operasi. Community of Publishing in Nursing (COPING), 5(3), 147-152.

Asmadi. (2008). Konsep Dasar Keperawatan. Jakarta: EGC.

Carpenito, L. J. (2013). Diagnosa Keperawatan: Aplikasi pada Praktek Klinik (6th ed.). Jakarta: EGC.

Ismiyatun, N. (2017). Hubungan Pemberian Komunikasi Terapeutik Dengan Tingkat Kecemasan Pasien Pre Operasi Di Rumah Sakit Umum Daerah Tugurejo Semarang. Universitas Muhamadyah Semarang.

Mirantia, I., Harmilah, \& Surantana. (2017). Therapeutic Communications Reduce The Patient's Anxiety Of Pre Operation Patients. In Proceeding Book The 4 th International Confrence On Health Science 2017 "The Optimalization of Adolescent Health in The Era of SDGs " (pp. 35-42).

Mulyani, S., Paramastri, I., \& Priyanto, M. 
Farida Febriyanti, dkk: Pengaruh Komunikasi Terapeutik Perawat Terhadap Tingkat Kecemasan Pada Pasien Pra Operasi

A. (2008). Therapeutic Relation and Communication of Nurse and Patient for. Berita Kedokteran Masyarakat, 24(3), 151-155.

Purwaningsih, \& Karlina. (2012). Asuhan Keperawatan Jiwa (2nd ed.). Yogyakarta: Nuha Medika.

Stuart, G. W. (2007). Buku Saku Keperawatan Jiwa (5th ed.). Jakarta: EGC.

Warsini, W., Irwanti, W., \& Siswanto, R. A. (2016). Komunikasi Terapeutik Perawat dengan Tingkat Kecemasan Pasien Pre-Operasi di Ruang Instalasi Bedah Sentral RSUD Saras Husada Purworejo. Jurnal Ners Dan Kebidanan Indonesia, 3(2), 96. 